Viso - Cadernos de estética aplicada Revista eletrônica de estética

ISSN 1981-4062

No 24, jan-jun/2019

http://www.revistaviso.com.br/
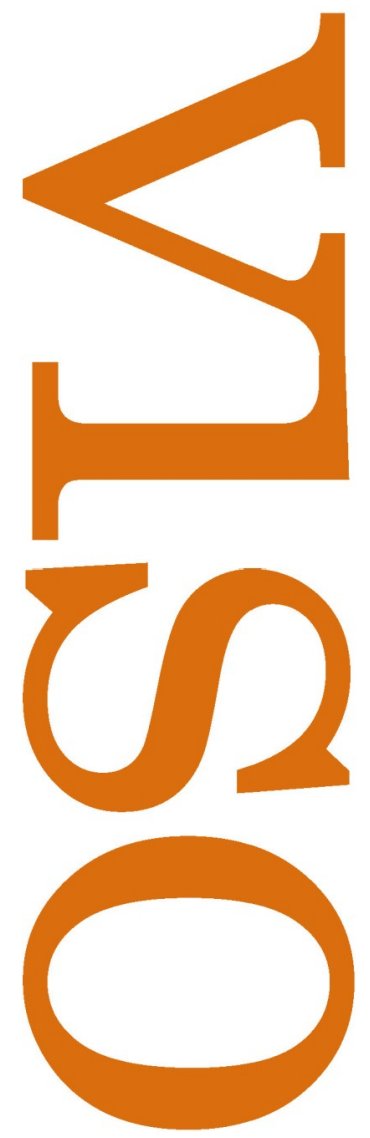

\title{
Utupë: A imaginação conceitual de Davi Kopenawa
}

Marco Antonio Valentim

Universidade Federal do Paraná (UFPR)

Curitiba, Brasil 


\section{RESUMO}

\section{Utupë: A imaginação conceitual de Davi Kopenawa}

Pretendo oferecer uma interpretação do conceito yanomami de imagem tendo por foco sua exegese xamânica por Davi Kopenawa em A queda do céu. Para tanto, proponho três níveis sucessivos de consideração: uma exposição do conceito de imagem; a interpretação da imagem como forma espectral; uma comparação, de significado político, da conceitualidade xamânica com outras imagens filosóficas do conceito. Veremos que o conceito incorporado por Kopenawa implica uma modalidade inteiramente outra de imaginação conceitual, "outro modo de criação de conceitos que não o 'filosófico', no sentido histórico-acadêmico do termo" (Viveiros de Castro). Afinal, a ontocosmologia em questão é, sobretudo, "uma experiência corporal dos xamãs" (Albert).

Palavras-chave: imagem - conceito - espectro - xamanismo - política

\section{ABSTRACT}

\section{Utupë: Davi Kopenawa's Conceptual Image}

I intend to offer an interpretation of the yanomami concept of image focused on its shamanic exegesis provided by Davi Kopenawa in The Falling Sky. In order to do so, I propose three successive levels of consideration: an exposition of the concept of image; the interpretation of image as spectral form; a comparison, with political meaning, between shamanic conceptuality and other philosophical images of concept. We shall see that the concept embodied by Kopenawa implies an entirely other modality of conceptual imagination, "another way of creating concepts than the 'philosophical', in the historicalacademic sense of the term" (Viveiros de Castro). After all, the ontocosmology at stake is mainly "a bodily experience of the shamans" (Albert).

Keywords: image - concept - spectre - shamanism - politics 


\section{VALENTIM, M. A. "Utupë: A imaginação conceitual de Davi Kopenawa". In: Viso: Cadernos de estética aplicada, v. XII, n. 24 (jan-jun/2019), pp. 193-216.}

DOI: $10.22409 / 1981-4062 / v 24 i / 317$

Aprovado: 04.02.2019. Publicado: 30.06.2019.

(C) 2019 Marco Antonio Valentim. Esse documento é distribuído nos termos da licença Creative Commons Atribuição-NãoComercial 4.0 Internacional (CC-BY-NC), que permite, exceto para fins comerciais, copiar e redistribuir o material em qualquer formato ou meio, bem como remixá-lo, transformá-lo ou criar a partir dele, desde que seja dado o devido crédito e indicada a licença sob a qual ele foi originalmente publicado.

Licença: http://creativecommons.org/licenses/by-nc/4.0/deed.pt BR

Accepted: 04.02.2019. Published: 30.06.2019.

(C) 2019 Marco Antonio Valentim. This document is distributed under the terms of a Creative Commons Attribution-NonCommercial 4.0 International license (CC-BY-NC) which allows, except for commercial purposes, to copy and redistribute the material in any medium or format and to remix, transform, and build upon the material, provided the original work is properly cited and states its license.

License: http://creativecommons.org/licenses/by-nc/4.0/ 
there's more to the picture than meets the eye - Neil Young

"Centro de gravidade da ontologia e da cosmologia dos Yanomami", o conceito de utupë - "imagem" - ocupa um lugar principal no pensamento de Davi Kopenawa. ${ }^{2}$ Em A queda do céu, ele possui várias dimensões, comparecendo a propósito da discussão encetada por Kopenawa a respeito da divergência política entre os Yanomami e os brancos [napë] quanto à conservação da floresta - pois a agência destrutiva destes é imputada a um certo regime imagético -, do estatuto ontológico dos brancos - cujas imagens variam de espíritos ancestrais protetores da floresta a monstros canibais responsáveis por sua devastação - e da cataclismologia epitomizada pela "queda do céu" - evento cósmico resultante de uma verdadeira "guerra de imagens". ${ }^{3} \mathrm{O}$ conceito também é decisivo na explicação da própria natureza "literária" da obra, caracterizada por uma defasagem irremediável entre imagem e letra ${ }^{4}$, bem como pela apropriação da escrita para a produção de um corpo-arma xamânico, capaz de provocar, mediante "peles de imagens", uma vertiginosa alteração no pensamento letrado dos brancos: trata-se de "um livro único que libera da ilusão do livro". ${ }^{5}$ Mas, sobretudo, por narrar a trajetória espiritual de Kopenawa através de diferentes mundos e, com isso, a múltipla transformação de sua própria imagem - seu "devir-outro" ${ }^{-}$- A queda do céu descreve a história de um espectro. ${ }^{7}$

\section{Seres-imagens}

No capítulo 4 do livro, "Os ancestrais animais", lemos:

[i] Todos os seres da floresta possuem uma imagem utupë. São essas imagens que os xamãs chamam e fazem descer. São elas que, ao se tornarem xapiri, executam suas danças de apresentação para eles. São elas o verdadeiro centro, o verdadeiro interior dos animais que caçamos. São essas imagens os animais de caça de verdade, não aqueles que comemos! São como fotografias destes. Mas só os xamãs podem vê-las. A gente comum não consegue. Em suas palavras, os brancos diriam que os animais da floresta são seus representantes. O guariba iro que flechamos nas árvores, por exemplo, é outro que sua imagem Irori, o espírito do guariba, que os xamãs podem chamar a si. Essas imagens de animais tornados xapiri são muito bonitas mesmo quando fazem suas danças de apresentação para nós, como os convidados no começo de uma festa reahu. Os animais da floresta, em comparação com elas, são feios. Existem, sem mais. Não fazem senão imitar suas imagens. Não passam de comida para os humanos.

[ii] No entanto, quando se diz o nome de um xapiri, não é apenas um espírito que se nomeia, é uma multidão de imagens semelhantes. Cada nome é único, mas os xapiri que designa são sem número. São como as imagens dos espelhos que vi em um dos hotéis onde dormi na cidade. Eu estava sozinho diante deles mas, ao mesmo tempo, tinha muitas imagens idênticas espalhadas neles. Assim, há um só nome para a imagem da anta xama enquanto xapiri, mas existem muitíssimos espíritos anta que chamamos de xamari pë. É assim com todos os xapiri. Há quem pense que cada um é único, mas suas imagens sempre são muito numerosas. Apenas seus nomes não o são. São como 
eu, de pé diante dos espelhos do hotel. Parecem únicos, mas suas imagens se justapõem ao longe sem fim.

[iii] As imagens de animais que os xamãs fazem dançar não são dos animais que caçamos. São de seus pais, que passaram a existir no primeiro tempo. São, como disse, as imagens dos ancestrais animais que chamamos yarori. Há muito e muito tempo, quando a floresta ainda era jovem, nossos antepassados, que eram humanos com nomes animais, se metamorfosearam em caça. Humanos-queixada viraram queixadas; humanos-veado viraram veados; humanos-cutia viraram cutias. Foram suas peles que se tornaram as dos queixadas, veados e cutias que moram na floresta. De modo que são esses ancestrais tornados outros que caçamos e comemos hoje em dia. As imagens que fazemos descer e dançar como xapiri, por outro lado, são suas formas de fantasma [revenants]. São seu verdadeiro coração, seu verdadeiro interior. Os ancestrais animais do primeiro tempo não desapareceram, portanto. Tornaram-se os animais de caça que moram na floresta hoje. Mas seus fantasmas [spectres] também continuam existindo. Continuam tendo seus nomes de animais, mas agora são seres invisíveis. Transformaram-se em xapiri que são imortais. Assim, mesmo quando a epidemia xawara tenta queimá-los ou devorá-los, seus espelhos sempre voltam a desabrochar. São verdadeiros maiores. Não podem desaparecer jamais.

[iv] É verdade. No primeiro tempo, quando os ancestrais animais yarori se transformaram, suas peles se tornaram animais de caça e suas imagens, espíritos xapiri. Por isso estes sempre consideram os animais como antepassados, iguais a eles mesmos, e assim os nomeiam. Nós também, por mais que comamos carne de caça, bem sabemos que se trata de ancestrais humanos tornados animais. São habitantes da floresta, tanto quanto nós. Tomaram a aparência de animais de caça e vivem na floresta porque foi lá que se tornaram outros. Contudo, no primeiro tempo, eram tão humanos quanto nós. Eles não são diferentes. Hoje, atribuímos a nós mesmos o nome de humanos, mas somos idênticos a eles. Por isso, para eles, continuamos sendo dos seus. ${ }^{8}$

O primeiro parágrafo [i] começa por afirmar a imagem como centro, "verdadeiro interior", dos seres da floresta. Isso se justifica pelo fato de as imagens "tornarem-se" xapiri; são elas que se apresentam aos xamãs, como espíritos ou sujeitos sobrenaturais. De outro lado, os animais de caça são caracterizados como "representantes" dessas imagens, com estas últimas sendo, por sua vez, explicadas como "fotografias" daqueles: os animais "não fazem senão imitar suas imagens". Existindo "sem mais", eles são caça, "comida para os humanos", em contraposição às imagens-xapiri, jamais comestíveis. Ademais, se lembrarmos a sentença que abre esse capítulo - "Os xapiri são as imagens dos ancestrais animais yarori que se transformaram no primeiro tempo" ${ }^{-}-$, ressalta principalmente a estranha e complexa condição imagética dos espíritos: sob um aspecto, são a essência de seus representantes ou imitações; sob outro, seus simulacros; e, sob outro ainda, como Kopenawa afirma mais à frente, imagens dos ancestrais míticos. Logo, seriam os animais de caça, enquanto seres atuais, imagens de imagens? E essas imagens, os xapiri, consistem em formas substanciais ou em cópias de originais?

O segundo parágrafo [ii] explica a mesma condição imagética mediante duas características principais dos xapiri, a saber, sua multiplicidade "sem número" e sua autossimilaridade fractal, especular: "Quando se diz o nome de um xapiri, não é apenas 
um espírito que se nomeia, mas uma multidão de imagens semelhantes"; "São como as imagens dos espelhos que vi em um dos hotéis onde dormi na cidade". Mais uma vez, assim como no caso de "fotografias" e "representantes", Kopenawa faz uso metafórico de termos oriundos do mundo dos brancos para explicar (aliás, aos mesmos brancos) o ser das imagens. Esse uso é coerente com o contraste esboçado entre imagens e nomes: sendo únicos, estes diferem essencialmente daquelas, que se multiplicam sem fim. A nomeação parece, assim, ser de todo inadequada à designação das imagens-xapiri: "Há um só nome para a imagem da anta xama enquanto xapiri, mas existem muitíssimos espíritos antas que chamamos de xamari pë". Seria, pois, a pluralidade fractal ("multitude") uma propriedade essencial dos espíritos, que os torna resistentes à designação nominal? Será o nome algo totalmente distinto de uma imagem ou, se não, uma modalidade de imagem?

O terceiro parágrafo [iii] introduz os ancestrais míticos yarori como ocupantes do vértice de uma "triangulação ontológica" que reúne também os animais de caça e os espíritos xamânicos, "constitui[ndo] uma das dimensões fundamentais da cosmologia yanomami". ${ }^{10}$ Tais seres correspondem aos originais dos quais os xapiri são as imagens; é em relação a eles que se conforma o complexo espelhamento entre os espíritos e os animais: estes imitam os espíritos, que são imagens dos ancestrais. O jogo cosmológico das imagens congrega esses três pólos ou vértices, e sua lógica é transformacional. Sujeitos a uma "irresistível propensão ao 'devir-animal' (yaroprai)"11, os ancestrais "metamorfosearam-se em caça". Mas a metamorfose não acontece(u) em sentido único: tornando-se animais, "peles", os animais transformaram-se também em espíritos, "fantasmas", de modo que peles animais e fantasmas espirituais formam um duplo aspecto - respectivamente, o visível e o invisível aos olhos da "gente comum" assumido pelos ancestrais míticos. Se, "no primeiro tempo", estes "eram humanos com nomes animais", humano-animais, no presente cosmológico os dois aspectos se encontram necessariamente dissociados; não obstante, a transformação supostamente definitiva dos ancestrais em animais não é irreversível, perfazendo uma potencialidade cosmológica de fundo que jamais se esgota. Segundo Kopenawa, eles "não desapareceram", persistindo, sob forma monstruosamente humana, como espíritos. Significa que animais e espíritos são aspectos distintos dos mesmos sujeitos (os ancestrais originários)? Ou, ao contrário, que chegam a constituir entidades realmente independentes (animais, de um lado, e espíritos, de outro)? Ou ainda, as duas coisas, enquanto aspectos-sujeitos em que se transformam os ancestrais?

O último parágrafo [iv] explicita, com base no vínculo entre ancestrais, animais e espíritos, um entrecruzamento de perspectivas. Trata-se do mútuo espelhamento dos sujeitos, através de que uns projetam sobre os outros suas imagens - com a notável inclusão dos humanos [yanomae thëpë]: "[Os espíritos] sempre consideram os animais como antepassados, iguais a eles mesmos, e assim os nomeiam"; "Nós [os humanos] também, por mais que comamos carne de caça, bem sabemos que se trata de ancestrais humanos tornados animais"; "Para eles [os animais], continuamos sendo dos 
seus". Essa projeção testemunha, a partir de uma origem ancestral comum a humanos e animais, que "todos fazíamos parte da mesma gente"12, uma vez que na origem os animais "eram tão humanos quanto nós". Mas tal fundo comum não oblitera e parece possibilitar divergências de perspectiva, provenientes do fato de que aquela projeção imagética transforma, para além de seus nomes, o próprio ser dos sujeitos. "Embora sejamos humanos, eles [os animais] nos chamam pelo mesmo nome que dão a si mesmos", o que faz com que a condição excepcional que os humanos reivindicam para si ("nós, que não viramos caça") apareça como obra de fingimento, autodissimulação: "Por isso acho que nosso interior é igual ao da caça, mesmo se atribuímos a nós mesmos o nome de humanos, fingindo sê-lo". ${ }^{13}$ Assim, os espíritos veem os yanomae thëpë como outros que humanos, imagens dos mortos: "Em seus olhares, já somos fantasmas, porque, ao contrário deles, somos fracos e morremos com facilidade". ${ }^{14}$

De início, perguntávamos se animais e espíritos constituiriam aspectos dos ancestrais ou pessoas independentes; agora, percebemos que a subjetivação dos aspectos como portadores de perspectiva sobre os humanos leva, paradoxalmente, a uma intensificação do caráter ontológico de imagem desses diversos sujeitos. Seriam, pois, os animais de caça e os espíritos xamânicos, a exemplo dos próprios ancestrais míticos, diferentes espécies de "seres-imagens"? ${ }^{15}$ Mais ainda, será a própria humanidade, enquanto condição existencial, uma imagem "fingida", resultado de autotransfiguração diante da alteridade extra-humana?

\section{"Como um outro dentro"}

Comentando o conceito yanomami de imagem, Albert diz:

A imagem (utupë) é primeiro um componente da pessoa. Ela está assim, enquanto "imagem-vital", contida no "corpo-pele" (siki) de cada ser e garante sua animação. Mas, sob forma não-corpórea, é igualmente uma "imagem-essência" original que os xamãs podem convocar a título de espírito auxiliar. Ela se torna assim "imagem-espírito" xamânico. Utupë designa também o reflexo (na água, nos espelhos), a sombra que se traz, o desenho, a fotografia, as reproduções (brinquedos, miniaturas). Utupa sipë ("peles de imagens") designa os jornais e as revistas. ${ }^{16}$

Assim descrito, o conceito de imagem congrega significados aparentemente antagônicos: imagem como contida no corpo (vida), mas também como separada dele (alma); imagem como essência original (arquétipo), mas também como reflexo e reprodução (simulacro); imagem como forma das coisas (categoria), mas também como sujeito espiritual (pessoa). A própria tradução do termo yanomami por "imagem" resulta, segundo o etnólogo, de um equívoco produtivo, motivado pelo fato de que os Yanomami "qualificam todas as manifestações de nossa iconofilia (imagens sobre papel ou digitais, animadas ou não), representações plásticas diversas (desenhos, gravuras, pinturas, estátuas) ou modelos reduzidos (brinquedos e miniaturas) pelo mesmo termo - utupë". ${ }^{17}$ 
Por outro lado, Albert destaca que o seu significado mais eminente é aquele em que o termo designa o "valor de espectro" [pë në porepë] dos ancestrais humano-animais das origens ${ }^{18}$ - valor que "o xamanismo permite restaurar e reatualizar" sob as forma dos xapiri, "seres-imagens" que povoam livremente o mundo suportando a "dinâmica dos fenômenos visíveis". ${ }^{19}$ A partir de um conjunto de etnografias yanomami, Leite sugere que utupë, principal componente da pessoa, confunde-se com a espectralidade enquanto "potencial de alteração" pelo qual sujeitos (humanos, por exemplo) se formam sob a perspectiva de outros sujeitos, radicalmente diferentes (extra-humanos). ${ }^{20}$ Poder-se-ia então inferir que imagem se atualiza como agência espectral: a utupë de uma pessoa é o "núcleo dinâmico" do seu espectro ${ }^{21}$, que a vincula de imediato, intrinsecamente, a outrem: "como um outro dentro do Sanumá que vemos". ${ }^{22}$

Todavia, como podemos compreender tal pletora de significados, sendo alguns inconciliáveis - arquétipo, de um lado, e simulacro, de outro; categoria, de um lado, e pessoa, de outro? O conceito de utupë parece ser tão múltiplo quanto suas instâncias concretas de (trans-)figuração. Donde a inevitável questão:

O que seria uma imagem se, em um outro mundo intelectual e humano possível, é essa alma das coisas? Se há conceito de imagem, deve ser válido de modo mais ou menos universal; portanto, o que seria um conceito de imagem universal que pudesse incluir todas as coisas que os Yanomami colocam nesse conceito de utupë do qual nos falam ser o equivalente do nosso? O que seria uma noção de imagem que englobasse a deles e a nossa? ${ }^{23}$

Em primeiro lugar, convém esclarecer que estamos aqui muitíssimo longe de qualquer espécie de platonismo, seja de orientação realista ou idealista. A tese de Kopenawa de que os animais atualmente existentes apenas "imitam" suas imagens já oferece uma indicação cabal a esse respeito; afinal, aquilo que aí faria o papel de modelo possui consistência de imagem, sem confundir-se, pois, com uma cópia de realidade derivada nem com uma representação carente de existência real:

O conceito yanomami de utupë não pode ser reduzido à nossa noção de "imagem" enquanto representação figurada de uma realidade pré-existente sobre um meio qualquer (simulacrum). Além disso, ele não pode ser limitado ao registro de nossas "imagens mentais", imagens miragens que ressaltam também da representação analógica mas, desta vez, interior (phantasma). De fato, as imagens utupë dos seres primordiais descritas pelos xamãs com grande luxo de precisões estéticas o são, primeiramente, a título de percepções diretas de uma realidade exterior considerada como absolutamente tangível (o "ver" é aqui autenticamente um "conhecer") [...] As imagens não-icônicas dos xamãs yanomami [...] não podem senão abalar nossa concepção de imagem ao mesmo tempo sustentada pela oposição platônica entre eidos (forma verdadeira) e eikôn/eidôlon (reprodução, pseudo-semblante) e indissociável dos suportes pelos quais ela é proposta ao olhar (murais, painéis, pinturas, papéis, placas, telas). ${ }^{24}$

Para desdobrar esse ponto, é bastante oportuna a referência ao primeiro dos Apêndices de Lógica do sentido, "Platão e o simulacro". ${ }^{25}$ A separação platônica entre modelo, cópia 
e simulacro seria inspirada pelo propósito de distinguir entre o verdadeiro e o falso com base no critério da similitude: frente ao modelo, de forma sempre estável, a cópia seria uma "imagem dotada de similitude" e o simulacro uma "imagem sem semelhança" ${ }^{26}$ Para além do critério da similitude, o simulacro também tem seu modelo, um "modelo do Outro": a dessemelhança atua como critério positivo na determinação do ser de algo. O simulacro não é simplesmente o falso, mas o outro, o que difere, mantendo-se refratário à assimilação identitária. Ele não tem menos ser que a cópia; o seu ser consiste em "diferença interna" (da imagem consigo mesma, no sentido da transformação), oposta à "semelhança externa" (da cópia em relação ao modelo, no sentido da estabilização da forma). ${ }^{27}$ Donde a contraposição entre "duas leituras do mundo": "Uma nos convida a pensar a diferença a partir de uma similitude ou de uma identidade preliminar, enquanto a outra nos convida, ao contrário, a pensar a similitude e mesmo a identidade como produto de uma disparidade de fundo". ${ }^{28} \mathrm{~A}$ primeira leitura, filosófica, toma a diferença como derivada em relação à identidade; já a segunda, xamânica, assume que "a semelhança não existe em si", que "ela não passa de um caso particular da diferença, aquele em que a diferença tende a zero":29 "A primeira define exatamente o mundo das cópias ou das representações; coloca o mundo como ícone. A segunda, contra a primeira, define o mundo dos simulacros. Ela coloca o próprio mundo como fantasma". ${ }^{30}$

Em testemunho da aproximação ao xamanismo yanomami, tomemos um trecho do mito sobre a criação da humanidade atual por Omama, mito narrado por Ikahi a Albert (M 11) e que é contado também por Kopenawa: ${ }^{31}$

Quanto a nós, nós somos outra gente. Vocês estrangeiros, vocês também são pessoas diferentes e vocês foram obviamente criados depois - não é assim que foi? Nós que estamos aqui agora, nós éramos como fantasmas [ghosts] lá em cima no dorso do céu, e caímos por nossa vez e fomos criados na forma de outros Yanomam. Foi Omamë, também na forma de um fantasma [ghost], que nos criou por nossa vez. Essa camada terrestre, quando costumava ser o dorso do céu, era habitada pelos espectros [revenants] dos primeiros ancestrais, aqueles que morreram. É por isso que nós somos a forma espectral [spectral] daqueles ancestrais que caíram. ${ }^{32}$

Em nota, Wilbert \& Simoneau afirmam, citando o comentário de outro informante (Arianamë), que "a época da queda do céu [origem da humanidade atual] também é chamada 'o tempo em que o mundo se tornou espectral'". ${ }^{33}$ Fica claro, a partir disso, que a relação entre os ancestrais míticos e os humanos atuais não é de semelhança, por imitação derivativa, mas de dessemelhança, por transformação espectral. Os ancestrais não são modelos dos quais os humanos seriam cópias; ao invés disso, os humanos são os próprios ancestrais transformados: "Somos os fantasmas [revenants] da gente que saiu do céu". ${ }^{34}$ Ser fantasma/espectro de outrem não é ser sua cópia, fiel ou degradada, mas sim sua imagem transformada, ser outro em relação a outrem, e não semelhante em relação ao mesmo. 
Como vimos, Kopenawa compara os espíritos a simulacros (imagens de espelho), afirmando a multiplicidade como seu caráter essencial. A suposta unidade imutável da Ideia é ao mesmo tempo deslocada para o lado dos nomes, que constituem, por sua vez, apenas uma "aparência" dos espíritos. Bem às avessas do platonismo, temos uma espécie de nominalismo exorbitante, que submete a unidade do nome à multiplicidade da imagem. Um nome está para as imagens que designa como alguém, "sozinho", diante de seus reflexos em espelhos justapostos ao infinito... Há nisso uma inversão de fato radical do platonismo: os simulacros são "os verdadeiros maiores".

Ademais, os ancestrais humano-animais são caracterizados como eminentemente metamórficos. Teria sido, aliás, o descontrole de sua metamorfose generalizada que, segundo Kopenawa, ocasionara a queda do céu (e, com ela, a origem da humanidade atual). Ou seja, os supostos modelos, aos quais se tenderia a atribuir perfeita estabilidade de forma, comportam-se como simulacros, sujeitos à mais intensa alteração de forma. Os próprios ancestrais, seres originários dos quais os xapiri são imagens, possuem eles mesmos consistência imagética. Se os animais atuais são imagens dos espíritos (suas imitações), e se os espíritos são imagens dos ancestrais míticos (seus fantasmas), estes, por sua vez, são como que imagens de si mesmos (simulacros):

O que define os agentes e pacientes dos sucessos míticos é sua capacidade intrínseca de ser outra coisa: neste sentido, cada ser mítico difere infinitamente de si mesmo, visto que é "posto" inicialmente pelo discurso mítico apenas para ser "substituído", isto é, transformado. É esta auto-diferença que define um espírito e que faz com que todos os seres míticos sejam espíritos. ${ }^{35}$

Quanto a isso, convém ter em mente as ocorrências em que ora Kopenawa diz que os xapiri são "como os humanos", exibindo morfologia humanoide, ora diz que "não são como os humanos", incorporando características animais ou "quiméricas", como se sua forma oscilasse incessantemente entre antropomorfia e monstruosidade ${ }^{36}$ : "Um espírito é algo que só é escasso de corpo na medida em que possui corpos demais, capaz como é de assumir diferentes formas somáticas". ${ }^{37}$ Note-se que é tal "autodiferença" que permite aproximar os xapiri, imagens dos ancestrais, aos ancestrais, como imagens de imagens. Não fosse o poder de diferir de si mesmos, eles não poderiam manifestar "um caráter, em geral, excessivo em relação àquilo de que são a imagem" ${ }^{8}$ - tal como o "espírito lua", descrito com aparência de um humano envolto por claridade intensa, com barba e cabelos luminosos, tremulantes, dotado de caninos proeminentes e afiados, gargalhante..$^{39}$

Tal excesso monstruoso em relação àquilo de que se é imagem (ou seja, em relação à forma atual daquilo de que se é "representante") parece ser, então, eminentemente característico da condição espiritual/sobrenatural. Levando em conta a etimologia das entidades xamânicas [xapiri pë] correspondentes a animais, plantas e outros seres, Albert afirma que seus nomes são sempre formados pelo acréscimo do sufixo -ri ao 
nome do ente atual, a "denota[r] excesso, monstruosidade ou não-humanidade ('sobrenaturalidade')":

Por exemplo, a anta caçada é designada como xama a, ao passo que a imagem do ancestral humano-animal mítico Anta é chamada Xamari a. É essa imagem (utupë) do ancestral Xamari a, multiplicidade ao infinito, que os xamãs "fazem descer" e "fazem dançar" como espíritos auxiliares antas, xamari pë.40

Por sua vez, Viveiros de Castro explica o significado do sufixo correspondente na ontologia yawalapíti [-kumã] como marca de "uma alteridade do referente à essência do tipo", de modo que os arquétipos sobrenaturais dos entes atuais sejam marcados justamente por excesso e monstruosidade. $O$ arquétipo é assim o não-idêntico, o diferente: "O Outro é o Próprio, e vice-versa: todo modelo apresenta uma superabundância ontológica; toda superabundância é monstruosamente outra". ${ }^{41}$ "Platonismo?"42 Evidente que não!

\section{Espectrologia}

Tudo isso permite vislumbrar o caráter paradoxal da imagem utupë, ao mesmo tempo não-icônica e invisível:

Paradoxo aparente, portanto, de uma cultura focalizada sobre imagens xamânicas mas para a qual a iconicidade não tem nenhum interesse e que não concebe senão imagens "invisíveis" ou, ao menos, reservadas à visão da "gente-espírito" (os xamãs) e inacessíveis aos "olhos de fantasma" da "gente comum". ${ }^{43}$

Trata-se de imagem não-icônica porque, como vimos, não se assemelha àquilo que representa: "representantes que não são representações", "índices, não ícones". ${ }^{44} \mathrm{E}$ imagem invisível não só porque inacessível aos "olhos de fantasma" da gente comum, mas também, e sobretudo, porque se trata de imagens que veem, em lugar de serem vistas: "imagens ativas, índices que nos interpretam antes que as interpretemos; enigmáticas imagens que devem nos ver para que possamos vê-las" ${ }^{25}$ :

Os seres desconhecidos que apareciam em meus sonhos de criança eram espíritos xapiri que me olhavam e se interessavam por mim. Naquela época, eu ainda não sabia disso. Todas as imagens que via em sonho me deixavam muito apreensivo. Só bem mais tarde, quando meus antigos me deram de beber o poder da yãkoana, compreendi que, desde aquele tempo, elas tinham vindo ao meu encontro para que eu me tornasse um xamã. ${ }^{46}$

Em suma: o paradoxo de utupë é o de "imagens que seriam como a condição daquilo de que são imagens". ${ }^{47}$

Isso significa várias coisas. Primeiro, que os xapiri são condição dos animais de caça yaro: "o seu verdadeiro centro, verdadeiro interior", sem o qual eles não poderiam existir 
como tais (peles). Segundo, que os xapiri são, em certo sentido, condição dos ancestrais míticos yarori, condição como instância pela qual os ancestrais continuam existindo e agindo em meio à atualidade cósmica (como espíritos). É que, não fosse pela imaginação xamânica, o tempo mítico se confundiria com um passado imemorial, ao contrário de consistir no outro lado, virtual, do acontecimento. Terceiro, que os xapiri, sendo imagens, são por isso mesmo sujeitos/pessoas. Como diz Kopenawa a propósito da imagem do sol, isto é, do sol como (monstruosamente) humano:

Não falo aqui do sol mothoka, cujo calor cobre a floresta, e que é visto pelas pessoas comuns, mas da imagem do sol. Assim é. O sol e a lua têm imagens que só os xamãs são capazes de fazer descer e dançar. Elas têm aparência de humanos, como nós, mas os brancos não são capazes de conhecê-las. ${ }^{48}$

Logo, a condição fundamental para ser humano ou gente, thëpë - de uma forma que excede de todo a própria "yanomamidade" como uma certa gente, yanomae thëpë - é ter/ser imagem (ser visto/ver). Em sentido sui generis, psykhé diz-se, em yanomami, utupë.

Não se trata aí, como para Aristóteles, de que "a alma jamais pense sem imagem", como se a cláusula "não sem imagem" assinalasse um limite crítico, sublunar, para o intelecto humano, em sua busca por conceber "os entes separados", puramente inteligíveis, ou em seu tornar-se ele mesmo "separado" em relação ao plano sensível das imagens: "Em que os primeiros pensamentos seriam diferentes de imagens [phantásmata]? Certamente nem estes nem os outros pensamentos são imagens, embora também não existam sem imagens". ${ }^{49}$ Para Kopenawa, as imagens mesmas pensam: a alma é imagem, forma espectral, alma-imagem. Não se trata do phantasma como dispositivo intermediário entre o intelecto e a coisa, mas da personitude do próprio "fantasma" ou, se quisermos, da coisa mesma enquanto sujeito (e não objeto) de perspectiva. Utupë é invisível, sob condições normais, não por ser "apenas" pensável, como o noumenon kantiano, mas porque pensa e vê, imagina, fazendo-se assim hipervisível, a "olhos de espírito". ${ }^{50}$

Mas, se é verdade que, no caso yanomami ou, mais geralmente, ameríndio, "o ponto de vista cria o sujeito", implicando sua originária "autodeterminação pelo outro", ele o faz "criando"-o, antes que estritamente humano, como espectro, isto é, marcado por uma "heteronomia primeira" ${ }^{1}$, que corresponde à sua essencial visibilidade para outrem. Refiro-me ao que, em outros termos, Luciani chama de "qualidade fractal" da pessoa ameríndia: "o encerramento do todo (de uma pessoa) na parte (de uma pessoa); a conversão de partes de pessoas em pessoas inteiras". ${ }^{22}$ Cada uma das imagens - mítica, atual e xamânica - de um mesmo sujeito constitui, por si só, uma pessoa distinta. Em verdade, sequer caberia falar aqui de um mesmo sujeito, dotado de unidade transcendental, já que cada sujeito consiste no agenciamento coletivo de diversas outras pessoas. A alma-imagem é, dessa maneira, uma relação entre pessoas, elas mesmas 
constituídas por imagens, ou seja, pelas relações entre outras, as quais trocam incessantemente suas partes, ou melhor, suas imagens.

Se utupë equivale ao "núcleo anímico da pessoa", cujos demais componentes - duplo espectral (bei a në borebi, ser por outrem não-humano), duplo animal (bei a në rishibi, ser pelos inimigos), duplo nominal (bei wãha, ser pelos parentes), duplo pessoal (bei bihi, ser por si próprio) $)^{53}$ - são modalidades suas, duplicidades da imagem, é porque perfaz uma "subjetividade" integralmente modal, espectral. Assim, para a explicação do conceito de thëpë (pessoa, "sujeito") a partir do conceito de utupë, tornam-se pertinentes os termos com que Romandini formula a base de sua espectrologia: "Uma subjetividade não é senão uma integral constituída pelas agências espectrais que the são constitutivamente extra-humanas". ${ }^{54}$ De fato, Kopenawa afirma sobre os humanos que os xapiri, formas espectrais dos ancestrais míticos yarori, "nos chamam 'pequena gente fantasma' [pore thëpë wei]". ${ }^{55}$

A declaração dos xapiri pode dar a entender, por extrapolação da perspectiva dos espíritos sobre os humanos, que a condição espectral equivale sem mais à mortalidade, como se tornar-se espectro fosse o mesmo que passar ao mundo dos mortos - povo inimigo dos vivos que habita as costas do céu. ${ }^{56}$ Mas supô-lo implica reduzir o sentido da espectralidade a apenas uma de suas atualizações, quando "agir/entrar em estado de fantasma (poremuu)" corresponde a "devir-outro", no sentido do deslocamento ontológico da imagem vital, utupë, de um sujeito. ${ }^{57}$ Tudo pode entrar em estado de fantasma: a "árvore pore hi, cuja pele se renova continuamente" 58 ; a floresta "doente e transformada pelas fumaças de epidemia"59; as crianças durante o sono ${ }^{60}$; os caçadores seduzidos pelas mulheres das águas ${ }^{61}$; a gente das águas, "que os olhos das pessoas comuns veem como peixes"62; Omama ${ }^{63}$; a carne de Davi durante sua iniciação ${ }^{64 ;}$ a visão dos humanos ${ }^{65}$; doença por ferimento do duplo animal ${ }^{66}$; pessoa vítima de feitiçaria ${ }^{67}$; "nossa própria imagem" ${ }^{\prime 6}$; um missionário em briga com o padrasto de Davi ${ }^{69}$; Teosi $i^{70}$; o sogro sem tabaco ${ }^{71}$; o céu atingido pela epidemia xawara ${ }^{72}$; ventos e tempestades ${ }^{73}$; "o sangue do ser da guerra Aiamori" ${ }^{14}$; as árvores plantadas pelos brancos nas cidades. ${ }^{75}$ Espectralidade não é, portanto, o atributo exclusivo de uma pessoa ou povo, mas o potencial metamórfico constitutivo de todo agente cósmico: o seu "ser"-imagem.

Um outro mito yanomami, narrado por Ikahi, expõe a mesma equivocidade em torno à condição espectral. Trata-se do "retorno dos fantasmas" (M 36): após a dizimação de parte considerável de uma comunidade, os "fantasmas dos mortos" retornam, interrompendo o luto dos vivos; dentre eles, o de uma menina, que, diante da alegria da mãe em revê-la, fita-a com "olhos e face da cor daquele fulgurante fogo canibal, terrificante fogo vermelho": "Era impossível enganar-se: ela parecia um fantasma [ghost]". ${ }^{76}$ De repente, um grande pássaro inhambu "começa a cantar":

Os fantasmas foram à sua procura. Um velho entre eles disse: "Crianças, minhas crianças, vocês não veem o grande inhambu? Ele está cantando. Procuramos, mas ele 
permanece invisível; nós nos reunimos em volta dele e, ainda assim, não o vemos. Chego o mais perto possível do lugar do qual o canto vem, mas meus olhos procuram e não o encontram." O grande inhambu estava lá empoleirado, à vista de todos, porém iludia os olhos dos fantasmas. Quando de súbito alçou voo, eles se assustaram; simplesmente desapareceram e o acompanharam ao céu..$^{77}$

O encontro entre vivos e mortos atualizado pela presença/ausência do inhambu assinala entre eles uma descontinuidade ontológica, "objetiva e social" - associada à continuidade, "subjetiva e social", entre humanos e animais -, que caracteriza as cosmologias ameríndias, sendo a razão de seu caráter "multinaturalista". ${ }^{78}$ Dito de outro modo, o mito expõe uma condição fantasmal de segunda potência: a espectralidade dos mortos, seus fantasmas, como evidência de sua pertença a um "quase-outro mundo"79, e também a do próprio inhambu, que habita ao mesmo tempo dois "mundos", entre os vivos e os mortos. Um encontro espectral!

Por conseguinte, em lugar da linhagem intelectualista que vai de Aristóteles a Kant, e à qual pertencem também Hobbes e Espinosa enquanto tenazes conjuradores de espectros $^{80}$, um paralelo muito mais adequado seria do xamanismo de Kopenawa com, por exemplo, a magia filosófica de Ficino - formas de "onirismo especulativo" ${ }^{81}$ capazes de exasperar à vertigem o filósofo crítico dos Sonhos de um visionário ${ }^{82}$... Mens in alieno conversa. ${ }^{83}$

\section{$O$ ataque dos queixadas}

No capítulo 3 de A queda do céu, "O olhar dos xapiri”, lemos:

A única coisa que me aconteceu na floresta quando era adolescente foi ser atacado pelos espíritos dos queixadas. Naquela época, eu não parava de caçar com os homens de minha casa. Certa vez, tínhamos perseguido um bando desses porcos-do-mato por bastante tempo. Era um final de tarde. Tínhamos conseguido cercá-los. Eles tinham desacelerado e estavam ao nosso alcance. Preparamo-nos para flechá-los, cada qual de um lado. Como os outros caçadores, escolhi uma presa e retesei meu arco com calma. Porém, de repente, os queixadas se dispersaram para todos os lados. Parte do bando deu meia-volta e veio correndo na minha direção. De repente, me vi cara a cara com aqueles animais, correndo enfurecidos para cima de mim. Aterrorizado, tentei escapar subindo numa árvore jovem, mas acabei tropeçando e caí. O choque com o solo foi violento e desmaiei por um instante. Foi tudo muito rápido. Apesar disso, os queixadas tiveram tempo de saltar por cima de mim, como se eu fosse só um tronco caído no chão. Passaram por cima de meu peito, um depois do outro, muito depressa, sem me tocar. Eram muitos, e cheiravam muito mal. O ranger de suas presas era aterrorizante. Foi nesse momento, acho, que suas imagens me atacaram. Na hora, porém, não percebi nada.

Depois de passarem, me levantei, ainda tremendo de medo, e me juntei a meus companheiros, que tinham conseguido flechar vários deles. Não disse nada acerca de minha desventura. Trinchamos a caça abatida e colocamos os pedaços em jamaxins trançados com folhas de palmeiras maima si e kõanari si. Anoitecia, e estávamos muito 
longe de nossa casa. Decidimos acampar em plena floresta, e cozinhar tripas de queixada em embrulhos de folhas, para acalmar nossa fome de carne. Uma vez satisfeito, adormeci com tranquilidade. Mas no meio da noite comecei a me sentir muito mal. Acordei sobressaltado e, de repente, vi tudo à minha volta com olhos de fantasma [revenant]. Comecei a vomitar. Então, pensei: "Os queixadas são ancestrais mesmo! Fui atacado por suas imagens e são elas que me deixam doente!". No dia seguinte, voltamos para a nossa casa. Eu estava muito fraco, não podia carregar nada. Na noite seguinte, continuava doente. Dormi de novo em estado de fantasma [spectre]. Foi nesse momento que os espíritos queixada começaram a me aparecer em sonho. Um número incontável deles escapava de um enorme buraco na terra, do qual saía também um vendaval. Dançavam devagar com seus enfeites de penas, sobre um espelho que refletia uma luminosidade ofuscante. Isso durou muito tempo e, de repente, desapareceram. Então, acordei e pensei: "O que está acontecendo comigo? Como eu vou poder sarar?" ${ }_{44}$

Dessa narrativa releva o aspecto de utupë que mais nos interessa, em vista de discernirmos o traço mais característico da conceitualidade yanomami: o ataque dos queixadas - que não o tocam com seus corpos, mas o atingem com suas imagens - faz com que Davi reconheça que eles "são ancestrais mesmo". Ele constata empiricamente uma Ideia em uma atualização monstruosa do tempo mítico: "empirismo transcendental". ${ }^{85}$ Segundo Deleuze, isso significa nada menos que a criação de um conceito:

O empirismo empreende a mais louca criação de conceitos, uma criação jamais vista e maior que todas aquelas de que se ouviu falar. Ele trata o conceito como objeto de um encontro, como um aqui-agora, como um Erewhon de onde saem, inesgotáveis, os "aqui" e os "agora" sempre novos, diversamente distribuídos. Só o empirista pode dizer: os conceitos são as próprias coisas, mas as coisas em estado livre e selvagem, além dos "predicados antropológicos". ${ }^{86}$

Em outros termos, mais próximos à interpretação do xamanismo, a conceitualidade consiste no evento em que o mundo mítico, habitado pelos arquétipos, invade o presente histórico, e as ideias se revelam hiper-sujeitos: "Diz-se que as imagens vitais animais 'descem' ou que elas 'efetuam uma dança de apresentação' no peito das pessoas que experimentam qualidades de que elas constituem os arquétipos". ${ }^{87} \mathrm{~A}$ imaginação xamânica consiste assim em um modo eminente de "criação" pelo qual o conceito surge como imagem do "encontro sobrenatural" 88 de subjetividades heterogêneas, humanas e extra-humanas, atuais e ancestrais. Utupë é, então, um conceito de conceito.

É preciso notar que não se trata da relação representacional entre conceito e objeto, ou seja, da questão kantiana pela "possibilidade de uma representação que se relaciona com um objeto sem ser afetada de algum modo por ele": "Como pode o meu entendimento imaginar totalmente a priori conceitos de coisas com as quais estas devem concordar necessariamente?". ${ }^{99} \mathrm{O}$ que acontece com o conceito quando, pelo contrário, seu suposto objeto se impõe como um outro sujeito "em estado livre e selvagem, para além dos 'predicados antropológicos", logo, como fundamentalmente refratário ao reconhecimento segundo regras a priori de representação? O episódio de Davi com os 
queixadas, tomado no sentido de um ataque anímico, fornece um exemplo dessa outra forma de conceitualidade, na qual o "objeto" do conceito se revela, quando de sua imaginação, ser uma pessoa: "personagem conceitual" "animista": jamais meramente empírica, e sim contra-transcendental.

Se os ancestrais yarori são arquétipos dos animais yaro, os xapiri, ao personificar o tempo mítico na atualidade cósmica, são suas imagens-conceitos: "O mundo é povoado de seres imortais que remontam à origem do mundo", que "estão aí sempre, semidesencarnados, tornados categorias". ${ }^{91}$ Trata-se de espíritos (seres-imagens) ao invés de objetos (fetiches), como espécies "inimigas" de imagem - muito embora espíritos possam se transformar em objetos, como no caso de xapiri aprisionados como mercadorias nos museus dos brancos, e objetos possam virar espíritos, como no caso das mercadorias "afinizadas" na condição de adornos dos xapiri. ${ }^{92}$ Pois tudo é conceito, conceito-pessoa, personagem conceitual: espírito-espectro. Espectros são como espíritos veem outros (humanos, por exemplo); espíritos são como espectros (não) veem outros (animais, por exemplo); mas, sobretudo, espectros podem ser espíritos para outros (humanos ou animais): "Os espíritos veem os não-xamãs sob a forma de espectros; do mesmo modo, a invisibilidade usual dos espíritos aos olhos dos humanos não-xamãs é expressa dizendo-se que estes últimos possuem 'olhos de espectro'". ${ }^{93}$ Donde uma decisiva consequência para os napë: "Os Brancos, portanto, são todos espectros, e sempre espectros, uma vez que são supremamente incapazes de ver os espíritos". ${ }^{94}$ A espectralidade hiperbólica dos brancos - por incapacidade de "virar outro" - constituiria a razão ontocosmológica de sua conceitualidade objetivista - isto é, de seu pensamento "curto e obscuro". ${ }^{5}$

Conceitualidade é, por conseguinte, imaginação espectral, em que "o olhar dos xapiri" opera, em vez da "unidade originariamente sintética da apercepção" ${ }^{97}$, como condição suprema de possibilidade. Onde Kant situa a impossibilidade contrassensual da representação - se eu não fosse consciente de mim mesmo como sujeito único do pensamento, "nada seria para mim"98 -, Kopenawa encontra a multiplicidade originariamente disjuntiva da apercepção onírica: "Quem não é olhado pelos xapiripë não sonha, só dorme como um machado no chão". ${ }^{99}$ Apercepção disjuntiva, pois se trata de uma forma de pensamento na qual "a posição de sujeito como integral instável do Outro só pode advir em um corpo como efeito de disjunção". ${ }^{100}$ Não porque o corpo seja o suporte material ou correlato empírico do espírito, mas porque o próprio espírito consiste em certa constituição corporal cujo arranjo sempre instável, disjuntivo, encarna uma estrutura de pensamento intensamente transformacional, assubjetiva. Espírito é corpo, e corpo é espectro. De fato, que o corpo xamânico seja "por natureza" disjunto sobressalta na narrativa em que Kopenawa descreve a monstruosa dilaceração e recomposição da sua imagem pelos xapiri para o conserto do seu corpo-pensamento, transfigurado em tubo xamânico: 
Eu tinha perdido a consciência e foi minha imagem que eles desmembraram, enquanto minha pele permanecia no chão. Voaram para um lado com meu torso e para o outro com meu ventre e minhas pernas. Carregaram minha cabeça numa direção, e minha língua em outra [...] Mais tarde, os xapiri vieram juntar novamente os pedaços de meu corpo que haviam desmembrado. Porém, recolocaram meu torso e minha cabeça na parte de baixo de meu corpo e, ao inverso, minha barriga e minhas pernas na parte de cima. É verdade! Reconstruíram-me às avessas, colocando meu posterior onde era meu rosto e minha boca onde era meu ânus! [...] Depois substituíram minha língua pela que tinham consertado [...] Também trocaram minha garganta por um tubo, que chamamos purunaki, para eu poder aprender a cantar seus cantos e a falar com clareza. Esse tubo é a laringe dos espíritos. É dele que vem o sopro de suas vozes [...] Então, assim que eles recompuseram as partes de meu corpo, meu pensamento começou a desabrochar de novo. ${ }^{101}$

Eis aí uma imagem totalmente outra do conceito.

\section{Imaginação conceitual}

Se essa tese conclusiva não omite certo teor deleuzo-guattariano, convém não exagerálo no que se refere às consequências. Por um lado, os filósofos afirmam que os conceitos "povoam" o plano de imanência como "tribos que o habitam e nele se deslocam"102, mas, por outro, estabelecem uma rígida oposição entre figura e conceito: o pensamento "religioso" da transcendência hierárquica, projetiva (a "unidade imperial"), contraposto ao pensamento "filosófico" da imanência absoluta, conectiva (o "encontro do amigo") - a ponto de tal contraposição justificar um juízo inegavelmente etnocêntrico, conflitante com o espírito da "geofilosofia": "A filosofia foi uma coisa grega, embora trazida por migrantes". ${ }^{103}$ Logo, se o filósofo é, por excelência, "amigo do conceito", o xamã seria, por indigência pré-filosófica, "amigo da imagem"? ${ }^{104}$

Todavia, visto que o conceito, segundo os mesmos filósofos, "abandona toda referência para não reter senão conjugações e conexões que constituem sua consistência", se ele "não tem outra regra senão a da vizinhança, interna ou externa", e se "sua vizinhança ou consistência interna está assegurada pela conexão de seus componentes em zonas de indiscernibilidade" 105 , não seria forçoso reconhecer como filósofo, criador de conceitos, antes Kopenawa que Kant?! Afinal de contas, enquanto a filosofia transcendental procura estabelecer limites e fronteiras, circunscrevendo uma esfera de sentido exclusivamente humana - a cidade cosmopolita ${ }^{106}$-, o pensamento xamânico realiza a "comunicação transversal entre incomunicáveis", abrindo uma "zona transespecífica"107 de contágio entre humanos e extra-humanos - a "terra-floresta" [urihi a]:

[...] aprendi a conhecer um pouco o que os brancos chamam de política [...] Essa política não passa de falas emaranhadas. São só as palavras retorcidas daqueles que querem nossa morte para se apossar de nossas terras. Em muitas ocasiões, as pessoas que as proferem tentaram me enganar dizendo: "Sejamos amigos! Siga o nosso caminho e nós lhe daremos dinheiro! Você terá uma casa, e poderá viver na cidade, como nós!" [...] Na cidade, fico sempre ansioso e impaciente. Os brancos nos 
chamam de ignorantes apenas porque somos gente diferente deles. Na verdade, é o pensamento deles que se mostra curto e obscuro. Não consegue se expandir e se elevar, porque eles querem ignorar a morte. Ficam tomados de vertigem, pois não param de devorar a carne de seus animais domésticos, que são os genros de Hayakoari, o ser anta que faz a gente virar outro [...] Para nós, a política é outra coisa. São as palavras de Omama e dos xapiri que ele nos deixou. São as palavras que escutamos no tempo dos sonhos e que preferimos, pois são nossas mesmo. Os brancos não sonham tão longe quanto nós. Dormem muito, mas só sonham com eles mesmos. ${ }^{108}$

Mas será que nosso conceito de filosofia é capaz de suportar uma disparidade tão profunda entre "imagens do pensamento" 109 assim distintas? Talvez sim, caso se admita que "toda metafísica é mitofísica; sujeita, portanto, ao regime estrutural geral de 'verdade-como-variação', verdade em variação, como os mitos são". ${ }^{110}$ Desse ponto de vista, em que "não se trata de afirmar que xamãs são 'filósofos', ou vice-versa" 111 , o "mito da dignidade exclusiva da natureza humana"112, no qual se funda majoritariamente a metafísica ocidental, aparece como "variante estrutural dentro da imaginação mitopoética como faculdade de variação". ${ }^{113}$ Isso significa que "o 'conceito' não poderia ser senão um caso particular da 'figura"' 114 ... E a própria figuração teria de ser entendida de outra maneira, como composição da imagem do pensamento diante de/contra imagens divergentes. Da figuração, através do conceito, à espectralidade: metafísica como sonho, sonho como política.

Com efeito, no que diz respeito à divergência entre o cosmopolitismo filosófico moderno e a política cósmica ameríndia enquanto diferentes regimes de imagem - assimilação identitária versus transformação espectral -, Kopenawa assevera:

Hoje, os brancos acham que deveríamos imitá-los em tudo. Mas não é o que queremos. Eu aprendi a conhecer seus costumes desde a minha infância e falo um pouco a sua língua. Mas não quero de modo algum ser um deles. A meu ver, só poderemos nos tornar brancos no dia em que eles mesmos se transformarem em Yanomami. Sei também que se formos viver em suas cidades, seremos infelizes. Então, eles acabarão com a floresta e nunca mais deixarão nenhum lugar onde possamos viver longe deles. ${ }^{115}$

Impossível não evocar aqui a noção geofilosófica de "duplo devir":

É uma questão de devir. O pensador não é acéfalo, afásico ou analfabeto, mas se torna. Torna-se índio, não pára de se tornar, talvez "para que" o índio, que é índio, se torne ele mesmo outra coisa e possa escapar à sua agonia [...] É a relação constitutiva da filosofia com a não-filosofia. O devir é sempre duplo, e é este duplo devir que constitui o povo por vir e a nova terra. ${ }^{116}$

Contudo, em vista do "mesmo" devir, é preciso inverter a assimetria contida nessa imagem: se o napë-filósofo torna-se índio, não será antes porque o índio "vira" filósofoyanomami? E, se é este virar que permite aquele tornar-se, ao que se pode dizer que o filósofo (ocidental) escapa, através desse devir? De seu isolamento metafísico, sua 
angústia soberana, sua própria auto-imagem, enquanto fundamentos da conceitualidade branca?!

Seja como for, é inegável que a imaginação conceitual de Davi Kopenawa faz intrusão em nossa filosofia, ao realizar, em vez do saber como instituição do pensamento único (por mais "multicultural" que se esforce por ser), o sonho como modo pelo qual "nossos pensamentos podem crescer, caminhar e se multiplicar ao longe, em todas as direções": "Para nós, é esse o verdadeiro modo de conseguir sabedoria". ${ }^{117}$ Pondo-nos à escuta dos espíritos em suas "palavras dadas", experimentando nas peles de imagem "a disjunção que a[s] habita"118, poderíamos - "quem sabe?", cogita Davi119 - sonhar outros sonhos, sonhar com os outros.

\section{* Marco Antonio Valentim é professor do Departamento de Filosofia da UFPR.}

1 ALBERT, B. "Yanomami: retour sur image(s)". In: Fondation Cartier trente ans pour l'art contemporain, vol. 2. Paris: Fondation Cartier, 2014, p. 239.

${ }^{2}$ Para uma recensão de etnografias yanomami acerca do conceito de imagem, cf. LEITE, T. V. S. Pessoa e humanidade nas etnografias Yanomami. Dissertação de mestrado. Programa de PósGraduação em Antropologia Social do Museu Nacional/UFRJ, Rio de Janeiro, 2010, pp. 72-74.

${ }^{3}$ ALBERT, B. Op. cit., p. 238.

${ }^{4}$ Cf. CESARINO, P. de N. "Conflitos ontológicos e especulações xamanísticas em La chute du ciel, de Davi Kopenawa e Bruce Albert”. In: Sala Preta, São Paulo v. 15, n. 1 (2014), p. 206.

${ }^{5}$ GODDARD, J.-C. "Notas sobre A queda do céu de Davi Kopenawa y Bruce Albert por un lector blanco". In: ClimaCom, Campinas, v. 5 (2016), p. 76.

${ }^{6}$ KOPENAWA, D.; ALBERT, B. A queda do céu: palavras de um xamã yanomami. Tradução de Beatriz Perrone-Moisés. São Paulo: Companhia das Letras, 2015, p. 67.

${ }^{7}$ A versão brasileira da obra usa, com pouquíssimas exceções, o termo "fantasma" para traduzir porepë, ao passo que o texto francês diversifica, empregando ora revenant, ora spectre e, mais raramente, fantôme. Escapa-me de todo a lógica que preside essa variação em francês, quase abolida em português. Mas privilegiarei o termo "espectro", visto que suas ressonâncias filosóficas parecem ser menos estranhas à cosmologia yanomami do que aquelas que "fantasma" carrega consigo. Segundo argumenta Romandini, no conceito de fantasma se consolida, ao longo da história da metafísica ocidental, uma redução dos espectros como "entidades ontológicas próprias" ao "fenômeno noemático", condicionado pela "posição autônoma do homem ou da divindade": "Os fantasmas são progressivamente assimilados ao fenômeno noemático e, portanto, constituem um elemento dentro da ação do pensar. Não há espaço, então, para o fantasma como espectro, o qual, concomitantemente, se resolve em um resto inassimilável para a metafísica do pensar, da representação e do aparecer como fenômeno" (ROMANDINI, F. L. Principios de espectrología: la comunidade de los espectros II. Buenos Aires: Miño y Dávila Editores, 2016, pp. 139-140). A exemplo de consumação desse "progresso" metafísico, Hegel conclui da definição do espírito como "poder representacional da imaginação" a total submissão da imagem: "Quando olho alguma coisa, o que olho está em mim, pois sou eu que olho; ele é meu olhar. O espírito irrompe deste olhar, e olha o seu próprio olhar, isto é, o objeto como seu; o objeto suprimido como algo que é, a imagem. No olhar, espírito é imagem. A imagem pertence ao espírito, ele está na posse da imagem, é seu senhor; ela está guardada em seu tesouro, em sua noite" (HEGEL, G. W. F. Jenaer 
Systementwürfe III. Naturphilosophie und Philosophie des Geistes. Hamburg: Felix Meiner, 1987, p. 172).

${ }^{8}$ KOPENAWA, D.; ALBERT, B. Op. cit., pp. 116-118. Cf. Idem. La chute du ciel: paroles d'un chaman yanomami. Paris: Plon, 2010, pp. 98-100.

${ }^{9}$ Ibidem, p. 111.

${ }^{10}$ Ibidem, p. 621, n. 17.

${ }^{11}$ Ibidem, p. 614 , n. 1.

12 Ibidem, p. 473.

${ }^{13}$ Ibidem.

${ }^{14}$ Ibidem, p. 111.

${ }^{15}$ ALBERT, B. Op. cit., p. 240.

16 ALBERT, B; CHANDÈS, H. (orgs.). Yanomami - L'esprit de la forêt. Paris: Fondation Cartier/Actes Sud, 2003, p. 47, n. 2.

${ }^{17}$ ALBERT, B. Op. cit., p. 240.

${ }^{18}$ KOPENAWA, D. ; ALBERT, B. Op. cit., p. 621, n. 19.

${ }^{19}$ ALBERT, B. Op. cit., p. 240.

${ }^{20}$ LEITE, T. V. S. Op. cit., p. 66-71.

${ }^{21}$ ALBERT, B. Temps du sang, temps des cendres: représentation de la maladie, espace politique et système rituel chez les Yanomami du sud-est (Amazonie brésilliene). Thèse de doctorat, Laboratoire d'Ethnologie et de Sociologie Comparative/Université de Paris X-Nanterre, Paris, 1985, p. 146.

${ }^{22}$ GUIMARÃES, S. Cosmologia sanumá: o xamã e a constituição do ser. Tese de Doutorado. Programa de Pós-Graduação em Antropologia Social/UnB, Brasília, 2005, p. 130, apud LEITE, T. V. S. Op. cit., p. 67.

${ }^{23}$ SENRA, S. "Conversações em Watoriki - Das passagens de imagens às imagens de passagem: captando o audiovisual do xamanismo". In: Cadernos de subjetividade, São Paulo, v. 13 (2011), p. 72.

24 ALBERT, B. "Yanomami: retour sur image(s)". In: Fondation Cartier trente ans pour l'art contemporain, vol. 2. Paris: Fondation Cartier, 2014, pp. 240-241.

${ }^{25}$ Devo a Osiris Verissimo a referência à Lógica do sentido para comentar o conceito yanomami de imagem.

${ }^{26}$ DELEUZE, G. Lógica do sentido. Tradução de Luiz Roberto Salinas Fortes. São Paulo: Perspectiva, 2003, p. 263.

${ }^{27}$ Ibidem, p. 267.

${ }^{28}$ Ibidem.

${ }^{29}$ LÉVI-STRAUSS, C. O homem nu: Mitológicas IV. Tradução de Beatriz Perrone-Moisés. São Paulo: Cosac Naify, 2011, p. 35.

${ }^{30}$ DELEUZE, G. Op. cit., p. 267.

${ }^{31}$ KOPENAWA, D.; ALBERT, B. Op. cit., pp. 195-196.

${ }^{32}$ WILBERT, J.; SIMONEAU, K. Folk Literature of the Yanomami Indians. Los Angeles: University of California, 1990, pp. 41-42. 
${ }^{33}$ Ibidem, p. 42, n. 57. Grifo meu.

${ }^{34}$ KOPENAWA, D.; ALBERT, B. Op. cit., p. 196. Cf. Idem. La chute du ciel: paroles d'un chaman yanomami. Paris: Plon, 2010, p. 190.

35 VIVEIROS DE CASTRO, E. "A floresta de cristal: notas sobre a ontologia dos espíritos amazônicos”. In: Cadernos de campo, São Paulo, v. 14/15 (2006), p. 324.

${ }^{36}$ KOPENAWA, D.; ALBERT, B. Op. cit., pp. 111-131.

${ }^{37}$ VIVEIROS DE CASTRO, E. Op. cit., p. 326.

${ }^{38}$ Ibidem, p. 326.

${ }^{39}$ KOPENAWA, D.; ALBERT, B. Op. cit., pp. 93; 125.

${ }^{40}$ Ibidem, p. 587.

${ }^{41}$ VIVEIROS DE CASTRO, E. A inconstância da alma selvagem e outros ensaios de antropologia. São Paulo: Cosac Naify, 2002, p. 31.

42 Ibidem, p. 68. Sobre a "leitura tradicionalmente platonizante" do pensamento indígena e seu platonismo "apenas aparente", cf. também Ibidem, p. 444.

${ }^{43}$ ALBERT, B. Op. cit., p. 239.

44 VIVEIROS DE CASTRO, E. "A floresta de cristal: notas sobre a ontologia dos espíritos amazônicos". Op. cit., p. 325.

${ }^{45}$ Ibidem, p. 325.

${ }^{46}$ KOPENAWA, D. \& ALBERT, B. Op. cit., p. 93.

47 VIVEIROS DE CASTRO, E. "A floresta de cristal: notas sobre a ontologia dos espíritos amazônicos". Op. cit., p. 325.

${ }^{48}$ KOPENAWA, D.; ALBERT, B. Op. cit., p. 82. Grifo meu.

${ }^{49}$ ARISTÓTELES. De anima. Tradução de Maria Cecília Gomes dos Reis. São Paulo: Editora 34 , 2006, pp. 119-121 (431a-432a).

${ }^{50}$ KOPENAWA, D.; ALBERT, B. Op. cit., p. 118.

${ }^{51}$ VIVEIROS DE CASTRO, E. A inconstância da alma selvagem e outros ensaios de antropologia. Op. cit., pp. 373, 263, 241.

52 LUCIANI, J. A. K. "Fractalidade e troca de perspectivas". In: Mana, Rio de Janeiro, v. 7, n. 2 (2001), p. 102.

${ }^{53}$ LEITE, T. V. S. Op. cit., pp. 62-79. Os termos em língua nativa pertencem ao dialeto yanomam.

${ }^{54}$ ROMANDINI, F. L. Op. cit., p. 158.

${ }^{55}$ KOPENAWA, D.; ALBERT, B. Op. cit., p. 111.

${ }^{56}$ Ibidem, pp. 191-192.

${ }^{57}$ Ibidem, p. 615, n. 19.

${ }^{58}$ Ibidem, p. 83.

${ }^{59}$ Ibidem, p. 86.

${ }^{60}$ Ibidem, pp. 96-97.

61 Ibidem, p. 101.

62 Ibidem, p. 102. 
63 Ibidem, p. 119.

${ }^{64}$ Ibidem, p. 148.

${ }^{65}$ Ibidem, p. 167.

66 Ibidem, p. 181.

${ }^{67}$ Ibidem, p. 185.

${ }^{68}$ Ibidem, p. 212.

${ }^{69}$ Ibidem, p. 264.

70 Ibidem, p. 277.

${ }^{71}$ Ibidem, p. 320.

72 Ibidem, p. 368.

${ }^{73}$ Ibidem, p. 370.

${ }^{74}$ Ibidem, p. 426.

75 Ibidem, p. 471.

${ }^{76}$ WILBERT, J. ; SIMONEAU, K. Op. cit., p. 87.

77 Ibidem, pp. 87-88.

${ }^{78}$ VIVEIROS DE CASTRO, E. A inconstância da alma selvagem e outros ensaios de antropologia. Op. cit., p. 395.

79 Idem. Encontros - Eduardo Viveiros de Castro. Organização de Renato Sztutman. Rio de Janeiro: Beco do Azougue, 2008, p. 239.

${ }^{80}$ Cf. ROMANDINI, F. L. "Do espectro da metafísica à metafísica do espectro". In: Species, Curitiba, v. 1, pp. 9-15.

${ }^{81}$ VIVEIROS DE CASTRO, E. "O recado da mata". In: KOPENAWA, D.;ALBERT, B. A queda do céu: palavras de um xamã yanomami. Tradução de Beatriz Perrone-Moisés. São Paulo: Companhia das Letras, 2015, p. 40.

${ }^{82}$ Cf. KANT, I. "Sonhos de um visionário explicados por sonhos da metafísica". Tradução de Joãosinho Beckenkamp. In: KANT, I. Escritos pré-críticos. São Paulo: Unesp, 2005, pp. 141-218.

83 "Longe de toda fenomenologia da consciência transcendental e de uma unidade pura do intelecto [...] a mente humana, aqui, se desterritorializa, literalmente, ao entrar no mundo dos sonhos. A mente é permanentemente habitada pelas vozes divinas e espectrais, e a intimidade do eu (o que os modernos chamariam de self) é simplesmente o acesso a uma multiplicidade infinita de outros seres de razão que o habitam e o assediam. O homem nunca é plenamente si mesmo, jamais pode fechar-se sobre sua própria autonomia porque, de modo contínuo, é assediado pelas forças de um exo-mundo ao qual é permeável" (ROMANDINI, F. L. Principios de espectrología: la comunidade de los espectros II. Op. cit., p. 18).

${ }^{84}$ KOPENAWA, D.; ALBERT, B. Op. cit., pp. 103-104. Cf. Idem. La chute du ciel: paroles d'un chaman yanomami. Paris: Plon, 2010, pp. 82-84.

${ }^{85}$ Foi Marcos de Almeida Matos que me sugeriu a leitura do referido trecho de A queda do céu à luz do Prefácio de Diferença e repetição.

${ }^{86}$ DELEUZE, G. Diferença e repetição. Tradução de Luiz Orlandi e Roberto Machado. Rio de Janeiro: Graal, 1988, p. 17.

${ }^{87}$ ALBERT, B. Temps du sang, temps des cendres: représentation de la maladie, espace politique et système rituel chez les Yanomami du sud-est (Amazonie brésilliene). Thèse de doctorat, 
Laboratoire d'Ethnologie et de Sociologie Comparative/Université de Paris X-Nanterre, Paris, 1985, pp. 156-157.

${ }^{88}$ VIVEIROS DE CASTRO, E. A inconstância da alma selvagem e outros ensaios de antropologia. Op. cit., pp. 396-397.

${ }^{89}$ KANT, I. Dissertação de 1770/Carta a Marcus Herz. Tradução de António Marques. Lisboa: Imprensa Nacional-Casa da Moeda, 2004, p. 133.

${ }^{90}$ DELEUZE, G.; GUATTARI, F. O que é a filosofia?. Tradução de Bento Prado Jr. e Alberto Alonso Muñoz. Rio de Janeiro: Editora 34, 1992, pp. 83 e ss.

${ }^{91}$ VIVEIROS DE CASTRO, E. A inconstância da alma selvagem e outros ensaios de antropologia. Op. cit., pp. 68-69.

${ }^{92}$ KOPENAWA, D.; ALBERT, B. Op. cit., pp. 406-420, 421-438.

93 VIVEIROS DE CASTRO, E. "A floresta de cristal: notas sobre a ontologia dos espíritos amazônicos". Op. cit., p. 329.

${ }^{94}$ Ibidem, p. 329.

${ }^{95}$ KOPENAWA, D.; ALBERT, B. Op. cit., p. 390.

${ }^{96}$ Ibidem, pp. 89 e ss.

${ }^{97}$ KANT, I. Crítica da razão pura. Tradução de Manuela Pinto dos Santos e Alexandre Fradique Morujão. Lisboa: Fundação Calouste Gulbenkian, 2001, p. 131 (B132).

98 Ibidem, p. 131 (B132).

99 KOPENAWA, D. "Sonhos das origens". In: RICARDO, C. A. (ed.). Povos indígenas no Brasil, 1996-2000. São Paulo: Instituto Socioambiental, 2000, p. 19.

${ }^{100}$ ROMANDINI, F. L. Op. cit., p. 276. Grifo meu.

101 KOPENAWA, D.; ALBERT, B. Op. cit., pp. 153-154.

102 DELEUZE, G. ; GUATTARI, F. Op. cit., pp. 52-53.

103 Ibidem, pp. 117, 122.

${ }^{104}$ VIVEIROS DE CASTRO, E. Op. cit., p. 322.

${ }^{105}$ DELEUZE, G.; GUATTARI, F. Op. cit., p. 119.

${ }^{106}$ Cf. KANT, I. Ideia de uma história universal de um ponto de vista cosmopolita. Tradução de Rodrigo Naves e Ricardo Ribeiro Terra. São Paulo: Brasiliense, 1986.

107 VIVEIROS DE CASTRO, E. "Xamanismo transversal: Lévi-Strauss e a cosmopolítica amazônica”. In: QUEIROZ, R. C. \& NOBRE, R. F. (orgs.). Lévi-Strauss: leituras brasileiras. Belo Horizonte: Editora UFMG, p. 96.

${ }^{108}$ KOPENAWA, D.; ALBERT, B. Op. cit., p. 390. Grifo meu.

${ }^{109}$ DELEUZE, G. Proust e os signos. Tradução de Antonio Piquet e Roberto Machado. Rio de Janeiro: Forense Universitária, 2003, pp. 88-95.

110 VIVEIROS DE CASTRO, E. "Metaphysics as mythophysics, or, why I have always been an anthropologist". In: CHARBONNIER, P.; SALMON, G.; SKAFISH, P. (orgs.). Comparative Metaphysics: Ontology After Anthropology. London: Rowman \& Littlefield International, 2016, p. 261.

111 Ibidem, p. 261. 
112 LÉVI-STRAUSS, C. Antropologia estrutural dois. Tradução de Beatriz Perrone-Moisés. São Paulo: Cosac Naify, 2013, p. 53.

${ }^{113}$ VIVEIROS DE CASTRO, E. Op. cit., p. 261.

${ }^{114}$ Ibidem, p. 261.

${ }^{115}$ KOPENAWA, D.; ALBERT, B. Op. cit., p. 75. Cf. também Ibidem, pp. 274-290, e LUCIANI, J. A. K. Sobre a antimestiçagem. Tradução de Nicole Soares, Levindo Pereira e Marcos de Almeida Matos. Desterro [Florianópolis]: Cultura e Barbárie, 2016.

${ }^{116}$ DELEUZE, G.; GUATTARI, F. Op. cit., p. 142.

117 KOPENAWA, D.; ALBERT, B. Op. cit., p. 510.

${ }^{118}$ ROMANDINI, F. L. A ascensão de Atlas. Glosas sobre Aby Warburg. Tradução de Felipe Augusto Vicari di Carli. Desterro [Florianópolis]: Cultura e Barbárie, 2017, p. 71.

${ }^{119}$ KOPENAWA, D.; ALBERT, B. Op. cit., p. 65. 